\title{
PENGARUH PENILAIAN KESEHATAN BANK MENGGUNAKAN METODE RGEC TERHADAP PENINGKATAN JUMLAH NASABAH
}

\author{
Ika Amelia Sari ${ }^{1}$, Untung Lasiyono ${ }^{2}$ \\ Universitas PGRI Adi Buana Surabaya1,2 \\ Ikaa6966@gmail.com¹․ untunglasiyono@gmail.com²
}

\begin{abstract}
Penilaian kesehatan bank diukur dengan data keuangan yang merupakan aspek utama dalam menilai tingkat kesehatan bank. Pengkajian ini dipakai untuk membuktikan dampak yang ditimbulkan oleh Metode RGEC terhadap peningkatan jumlah nasabah. Populasinya adalah laporan keuangan PT BPRS JABAL NUR TEBUIRENG sampelnya berjumlah 36 dengan teknik purposive sampling. Analisis data menggunakan asumsi klasik, regresi linier berganda dan uji hipotesis (uji-F dan uji-T). Hasil Risk Profile mendapatkan sig $(0,008 \leq$ 0,05), menunjukkan Risk Profile mempengaruhi peningkatan jumlah nasabah, GCG mendapatkan sig $(0,360 \geq$ $0.05)$ menunjukkan GCG tidak menpengaruhi peningkatan jumlah nasabah, Earning mendapatkan sig $(0,002 \geq$ 0.05), Capital mendapatkan sig $(0,009 \geq 0.05)$ dari kedua variabel menunjukkan mempengaruhi peningkatan jumlah nasabah. Hasil uji-F didapatkan sig $(0,010 \leq 0,05)$ yang menunjukkan bahwa metode RGEC mempengaruhi peningkatan jumlah nasabah.
\end{abstract}

Kata kunci: Risk Profile, GCG, Earning , Capital dan Peningkatan Jumlah Nasabah

\section{ABSTRACT}

Bank health assessment is measured by financial data which is the main aspect in assessing the level of bank health. This study is used to prove the impact of the RGEC Method on increasing the number of customers. The population is a sample of 36 PT BPRS JABAL NUR TEBUIRENG financial statements with a purposive sampling technique. Data analysis uses classical assumptions, multiple linear regression and hypothesis testing (F-test and T-test). Risk Profile results get sig $(0.008 \leq 0.05)$, indicate Risk Profile affects the increase in the number of customers, GCG gets sig $(0.360 \geq 0.05)$ shows that GCG does not affect the increase in the number of customers, Earning gets sig $(0.002 \geq 0.05)$, Capital gets sig $(0.009 \geq 0.05)$ of the two variables showed an increase in the number of customers. F-test results obtained sig $(0.010 \leq 0.05)$ which shows that the RGEC method affects the increase in the number of customers.

Keyword: Profile, GCG, Earning, Capital and Increasing the Number of Customers

\section{PENDAHULUAN}

Negara kita yakni negara indonesia termasuk dalam kategori negara berkembang dimana kesejahteraan material berada pada tingkat yang rendah, tentu hal ini sangat berpengaruh terhadap kehidupan perekonomian di Indonesia. Sektor perbankan merupakan salah satu berperan penting dalam perekonomian. Karena bank berperan sebagai yang dapat menampung dana dan mengalirkan dana masyarakat. Bank dibagi menjadi dua dilihat dari fungsinya yakni Bank Umum dan Bank Perkreditan Rakyat (BPR). Di era sekarang ini BPR memiliki pasar tersendiri di dalam masyarakat. Pada umumya pengusaha kecil menengah cenderung memilih Bank Perkreditan Rakyat (BPR) sebagai tempat untuk mengembangkan usahanya dengan meminjam uang dengan bunga kredit yang kecil dan prosedur peminjamanya mudah.

Penilaian kesehatan bank diukur dengan data keuangan yang merupakan aspek utama dalam menilai tingkat kesehatan bank. Laporan keuangan adalah data keuangan yang dapat mengenali keadaan keuangan perusahaan pada saat ini atau dalam suatu kurun waktu tertentu (Kasmir,2012:7). 
Jumlah nasabah dapat mengalami peningkatan jika masyarakat merasakan adanya ketertarikan untuk menyimpan dananya pada bank. Faktor nasabah atau masyarakat memilih bank sebagai tempat mereka menyimpan dananya dengan melihat keadaan dari bank tersebut serta melihat tingkat kesehatan bank tersebut karena jika semakin banyak nasabah yang menyimpan dananya di bank semakin baik pula tingkat kesehatan bank tersebut.

Peningkatan jumlah nasabah yakni pertumbuhan pemakai jasa bank atau seseorang yang memiliki rekening pinjaman atau yang meminjam uang pada bank (M. Nur Arif Rianto,2010:189).

Dari latar belakang di atas maka peneliti melakukan penelitian dengan judul "Pengaruh Penilaian Kesehatan Bank Dengan Menggunakan Metode RGEC Terhadap Peningkatan Jumlah Nasabah Pada PT BPR SYARIAH JABAL NUR TEBUIRENG."

Dari kesimpulan diatas dapat dirumuskan masalah yaitu :

Pertama Risk Profile berdampak pada peningkatan jumlah nasabah,kedua Good Corporate Governance berdampak dalam peningkatan jumlah nasabah, ketiga Earnings berpengaruh dalam peningkatan jumlah nasabah, keempat capital berpengaruh dalam peningkatan jumlah nasabah, kelima metode RGEC berpengaruh dalam peningkatan jumlah nasabah.

\section{TINJAUAN PUSTAKA DAN HIPOTESIS}

Berikut ini merupakan pedoman serta referensi peneliti dalam melakukan penelitian diantaranya sebagai berikut :

1. Armanto witjaksono \& Monica nathalia (2016) membuat hasilnya variabel bebas berpengaruh sig terhadap variabel terikat.

2. Sumilat $C$ naftali,Ivone $V$ saerang,Joy $E$ tulung (2018). Hasil penelitian menunjukkan GCG, ROA, dan CAR berpengaruh signifikan terhadap Harga Saham sedangkan Risk Profile tidak berpengaruh Profile tidak berpengaruh signifikan terhadap Harga Saham.

3. Sesanti (2019). Hasil penelitian menunjukkan Risk Profile, GCG, ROA tidak berpengaruh dan CAR berpengaruh signifikan terhadap kepercayaan masyarakat .

\section{LANDASAN TEORI}

Bank adalah perusahaan yang menampung dana masyarakat dan mengalirkan kepada masyarakat serta memberikan jasa-jasa yang ada pada perusahaan (Kasmir,2016 : 3).

Laporan keuangan yaitu laporan yang berisikan data-data tentang keuangan perusahaan pada waktu sekarang atau kedepannya. Data tersebut untuk melihat keadaan dari suatu perusahaan (Kasmir,2013:7).

Bank bisa dikatakan sehat jika dapat mengaplikasikan peranan bank secara baik serta menjaga kepercayaan masyarakat, membantu perihal soal pembayaran dan dapat menerapkan kebijakan moneter (Permana,2012:2).

Peningkatan jumlah nasabah yakni pertumbuhan pemakai jasa bank atau seseorang yang memiliki rekening pinjaman atau yang meminjam uang pada bank (M. Nur Arif Rianto,2010:189). 


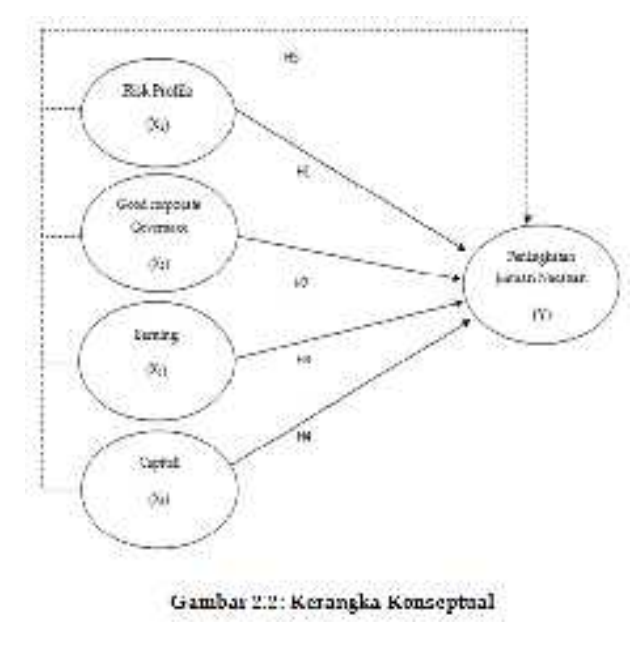

\section{HIPOTESIS PENELITIAN}

Adapun hipotesis yang peneliti yang di ajukan berdasarkan rumusan masalah diatas adalah sebagai berikut :

H1: Risk Profile bedampak pada peningkatan jumlah nasabah

H2: Good Corporate Governance berdampak pada peningkatan jumlah nasabah

H3: Earning berdampak pada peningkatan jumlah nasabah

H4: Capital berdampak pada peningkatan jumlah nasabah

H5: Metode RGEC berdampak pada peningkatan jumlah nasabah

\section{METODE}

Populasi peneletian ini memakai data laporan keuangan PT BPR Syariah Jabal Nur tebuireng. . Populasinya adalah laporan keuangan PT BPRS JABAL NUR TEBUIRENG sampelnya berjumlah 8 dengan teknik purposive sampling.Dalam penelitian ini sampelnya memakai data tahun 2012-2019. Kriteria yang ditentukan diantaranya :

1. Sampel penelitian memakai data laporan keuangan dan jumlah nasabah Pada PT BPR Syariah Jabal Nur Tahun 2012-2019.

2. Mempunyai kecukupan data yang sesuai dengan variabel tahun 2012-2019.

3. Bank yang mempunyai kelengkapan laporan yang diinginkan oleh peneliti.

Data yang digunakan merupakan data kuantitatif. Sumber data yang digunakan adalah data sekunder. Pengumpulan data dalam penenlitian ini adalah dokumentasi diambil dari data keuangan dan jumlah nasabah yang diambil di website Otoritas Jasa Keuangan (OJK) pada PT BPR Syariah Jabal Nur Tebuireng tahun 2012-2019.

\section{DEVINISI OPERASIONAL VARIABEL}

a. Risk Profile ( Profil Resiko)

Risk Profile merupakan penilaian atas kelayakan pemegang saham untuk bertanggung jawab atas suatu resiko investasi (kerugian). Penelitian ini diukur risiko kredit rumus: 
$\mathrm{NPF}=\underset{\text { Total Krrejit }}{\text { Ke Jit Bermasalah }} x 100 \%$

(Suuler : SE B] 19/24/DNDP)

b. Good Corporate Governance

Good Corporate Governance yakni cara untuk mengatur tentang suatu pengelolaan perusahaan supaya menghasilkan kualitas ekonomi jangka panjang yang berkelanjutan bagi para investor maupun pengemban kepentingan.

Tabel 2.3 Predilkat Kesehtatun Bank berdasalkan GCG

\begin{tabular}{|c|c|c|}
\hline Peringkat & Keterangan & Kriteria \\
\hline 1. & Sangogt taik. & Niax Kompest<1, \\
\hline 2. & Eak & 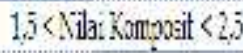 \\
\hline 3. & Culus: 3aik & 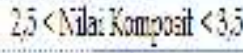 \\
\hline 4. & Kurang Eaik. & 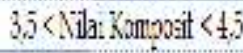 \\
\hline 5. & Tdak Baid & Neikompect $>4,5$ \\
\hline
\end{tabular}

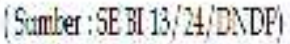

c. Earning (Rentabilitas)

Earning adalah faktor penting dalam menilai kesehatan bank yang menyangkut tentang kelayakan bank dalan memperoleh laba. Penilaian faktor rentabilitas diukur menggunakan rumus :

$$
\text { RO4 }=\frac{\text { taba sebelump pajak }}{\text { Totci iset }} \times 100 \%
$$

(Stunber:SE B1 13/24/DNDP)

d. Capital (Permodalan)

CAR adalah kelayakan modal yang membuktikan kapasitas bank dalam menjaga modal yang layak dan menajemen bank memadai dalam mengatur risiko yang dapat berdampak terhadapa modal bank. CAR dapat diukur menggunakan rumus yaitu :

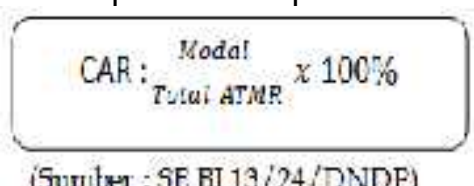

e. Peningkatan jumlah nasabah

Peningkatan jumlah nasabah yakni pertumbuhan pemakai jasa bank atau seseorang yang memiliki rekening pinjaman atau yang meminjam uang pada bank (M. Nur Arif Rianto,2010:189).

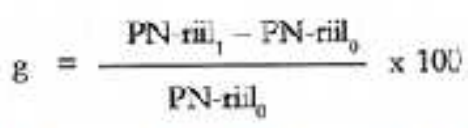

(sumber: sadono sulkimo,2013:49) 


\section{TEKNIK ANALISIS DATA}

Teknik analisis data pengkajian ini memakai uji hipotesis. Pengkajian ini memakai analisis regresi linier berganda dan uji asumsi klasik dengan memakai software aplikasi SPSS versi 2.4. HASIL

\section{UJI ASUMSI KLASIK}

Hasil uji normalitas data memakai uji kolmogrov-smirnov. Besarnya Asymp. Sig.(2-tailed) $(0,200 \geq 0,05)$ dan data menebar searah garis diagonal, maka data itu dinyatakan normal.

Hasil uji multikorelasi diperoleh nilai Tolarance untuk variabel Risk profile (X1) adalah $0,837 \geq$ 0,10, Good Corporate Governance (X2)adalah 0,667 $\geq 0,10$, Earning (X3) adalah 0,584 $\geq 0,10$ dan Capital (X4) adalah 0,554 $\geq 0,10$. Sedangkan nilai Variance Infaction Factor (VIF) Risk profile (X1) adalah 1,195 $\geq 10$, Good Corporate Governance (X2)adalah 1,477 $\geq 10$, Earning (X3) adalah 1,713 $\geq 10$ dan Capital (X4) adalah 1,806 $\geq 10$. Maka dilihat dari hasilnya bahwa regresi ini tidak terjadi gejala Multikolineritas.

Hasil dari uji heteroskedastisitas menurut grafik scatterplot menunjukkan plot atau titik-titik menebar dan tidak membentuk pola-pola tetentu. Dapat diisimpulkan bahwa regresi ini tidak mengalami masalah heteroskedastisitas.

Uji autokorelasi menyatakan bahwa angka Durbin Waston sebesar 1,724. bahwa regresi ini tidak ada autokorelasi

\section{ANALISIS REGRESI LINIER BERGANDA}

Analisis regresi linier berganda membuktikan diperoleh pesamaan garis regresinya yakni :

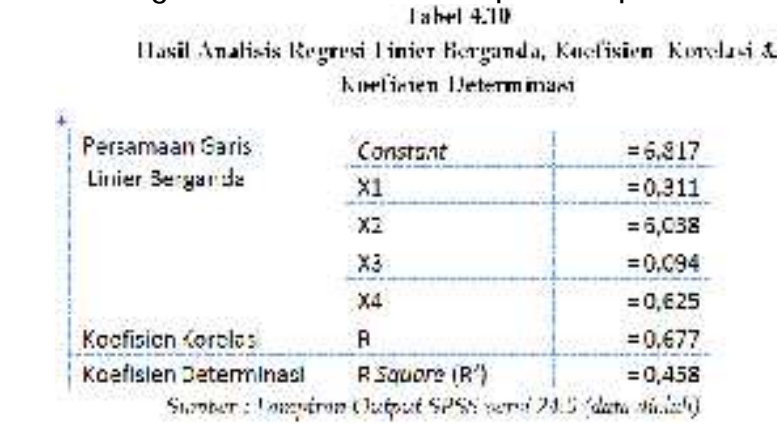

\section{$Y=6,817+0,311 X 1+6,038 X 2+0,094 X 3+0,625 X 4$}

Pada persamaan garis regresi diatas dapat dilihat dampak masing-masing variabel independen terhadap variabel dependennya diantaranya:

1. Konstanta $(\alpha)=6,817$, Berdasarkan hasil analisis regresi linier berganda, hal ini berarti bahwa apabila nilai keempat independennya bernilai 0 (nol), maka nilai peningkatan jumlah nasabah sebesar nilai koefisiennya yaitu 6,817.

2. Regresi Risk Profile $(X 1)=0,311$, menujukkan variabel Risk Profile $(X 1)$ mengalami peningkatan. maka pada jumlah nasabah mengalami peningkatan sebesar 0,311.

3. Good Corporate Governance $(X 2)=6,038$, menunjukkan variabel Good Corporate Governance (X2) mengalami peningkatan. maka pada jumlah nasabah mengalami peningkatan sebesar 6,038 .

4. Earning $(X 3)=0,094$, Hal ini berarti bahwa variabel Earning $(X 3)$ mengalami peningkatan. maka pada jumlah nasabah mengalami peningkatan sebesar 0,094. 
5. Capital $(X 4)=0,625$, Hal ini berarti bahwa variabel Capital $(X 4)$ mengalami peningkatan. maka pada jumlah nasabah mengalami peningkatan sebesar 0,625.

\section{KOEFISIEN KORELASI (R)}

Diperoleh hasil koefisien korelasi $(R)$ adalah 0,677. Nilai $R$ ini membuktikan seberapa besar hubungan antara variabel independan dan variabel dependen memiliki hubungan yang kuat.

\section{KOEFISIEN DETERMINASI (R2)}

Koefisien determinasi nilai $R$ Square $\left(R^{2}\right)$ yaitu 0,458 , hal ini membuktikan bahwa variabel terikat mempengaruhi variabel bebas yaitu $45,8 \%$ sedangkan $55,2 \%$ dapat diakibatkan oleh aspekaspek lain di luar variabel independenya.

\section{UJI HIPOTESIS}

\section{Hasil Uji - t (Parsial)}

Berdasarkan hasil tabel ini :

Taliel t:.1

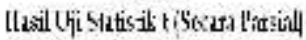

\begin{tabular}{|c|c|c|c|}
\hline Grisol ledspecor. & tliturs: & Sir & ketetinging \\
\hline $\begin{array}{l}\text { R.sb Polibe } \\
\text { Cocd Corovab? }\end{array}$ & 2.810 & c,cee & $\begin{array}{l}\text { Sqquilkau } \\
\text { lids: }\end{array}$ \\
\hline Gracclano & 1.344 & C,CE: & sinuilikan \\
\hline Farning. & 3.J41 & $\mathrm{C}, \mathrm{CC}$ & Signilikan \\
\hline ideritsl & 2,791 & $\mathrm{c}, \mathrm{Ccs}$ & Signifilinn \\
\hline
\end{tabular}

Berdasarkan hasil tabel 2 diatas, diperoleh nilai taraf signifikansi masing-masing variabel antara lain

Untuk variabel Risk Profile $\left(X_{1}\right)$ diperoleh nilai thitung sebesar 2,810 dengan taraf sig sebesar 0,008 berarti $\mathrm{H}_{1}$ diterima dan terbukti kebenarannya.

Untuk Good Corporate Governance $\left(\mathrm{X}_{2}\right)$ diperoleh nilai thitung sebesar 1,944 dengan taraf signifikan sebesar 0,061 berarti $\mathrm{H}_{2}$ ditoalak dan tidak terbukti kebenaranya.

Untuk variabel Earning $\left(X_{3}\right)$ Dari hasil perhitungan, diperoleh nilai thitung sebesar 3,041 dengan taraf signifikan sebesar 0,002 berarti $\mathrm{H}_{3}$ diterima dan terbukti kebenaranya.

Untuk vaiabel Capital $\left(\mathrm{X}_{4}\right)$ Dari hasil perhitungan, diperoleh nilai thitung sebesar 2,798 dengan taraf signifikan sebesar 0,009 berarti $\mathrm{H}_{4}$ diterima dan terbukti kebenaranya.

\section{Hasil Uji- F (Simultan)}

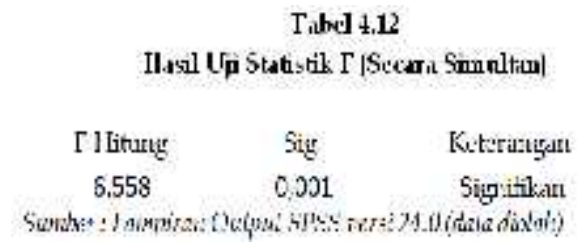

Berdasarkan hasil tabel 3, didapatkan nilai $F_{\text {hitung }}$ sebesar 6,588 dengan taraf sig sebesar 0,001 sehingga $\mathrm{H}_{5}$ diterima dan terbukti kebenarannya.

\section{SIMPULAN}


Berdasarkan hasil analisis regresi linier berganda dengan bantuan software SPSS (Statistical Package For Social Sciences) versi 24.0 dan pembahasan yang terdapat dalam bab sebelumnya maka dapat diberikan kesimpulan antara lain :

1. Hipotesis pertama dengan menggunkan Uji-t diperoleh nilai thitung $=2,810$ dan tingkat signifikan sebesar 0,008 sehingga 0,008 $<0.05$. Hal ini menunjukkan bahwa variabel Risk Profile berpengaruh terhadap peningkatan jumlah nasabah pada PT BPR Syariah Jabal Nur Tebuireng tahun 2017-2019.

2. Hipotesis kedua dengan menggunkan Uji-t diperoleh nilai thitung $=1,944$ dan tingkat signifikan sebesar 0,061 sehingga 0,061 > 0.05. Hal ini menunjukkan bahwa variabel Risk Good Corporate Governance tidak berpengaruh terhadap peningkatan jumlah nasabah pada PT BPR Syariah Jabal Nur Tebuireng tahun 2017-2019.

3. Hipotesis ketiga dengan menggunkan Uji-t diperoleh nilai thitung $=3,041$ dan tingkat signifikan sebesar 0,002 sehingga 0,002 < 0.05. Hal ini menunjukkan bahwa variabel Earning berpengaruh terhadap peningkatan jumlah nasabah pada PT BPR Syariah Jabal Nur Tebuireng tahun 2017-2019.

4. Hipotesis keempat dengan menggunkan Uji-t diperoleh nilai thitung $=2,798$ dan tingkat signifikan sebesar 0,009 sehingga 0,009 $<0.05$. Hal ini menunjukkan bahwa variabel Capital berpengaruh terhadap peningkatan jumlah nasabah pada PT BPR Syariah Jabal Nur Tebuireng tahun 2017-2019.

5. Hipotesis kelima dengan menggunkan Uji-F diperoleh nilai thitung $=6,558$ dan tingkat signifikan sebesar 0,001 sehingga 0,002 <0.05. Hal ini menunjukkan bahwa secara simultan keempat variabel bebas yaitu Risk Profile, Good Corporate Governance,Earning dan Capital berpengaruh terhadap peningkatan jumlah nasabah pada PT BPR Syariah Jabal Nur Tebuireng tahun 2017-2019.

\section{IMPLIKASI}

Dalam penelitian ini PT BPRS Jabal Nur Tebuireng selaku Bank perkreditan daerah supaya menjaga dan lebih mengembangkan tingkat kesehatan bank untuk masa yang akan datang. Dalam menerapkan metode RGEC pada bank untuk mengetahui baik tidaknya kemampuan bank dapat dinilai dari laporan keuanga dari bank tersebut. karena jika kesehatan suatu bank itu baik maka masyarakat atas kemampuan bank dalam mengolah keuangan bank.

\section{KETERBATASAN PENELITIAN}

Dalam pengkajian ini peneliti memiliki keterbatasan dan diantaranya :

1. Sampel yang digunakan hanya satu yakni pada PT BPRS Jabal Nur Tebuireng

2. Indikator yang digunakan untuk setiap variabel hanya terdapat satu indikator

3. Data yang digunakan memilki keterbatasan dalam pengambilan serta data yang diambil kemungkinan adanya kesalahan dalam penulisan oleh pihak bank tersebut. 


\section{DAFTAR PUSTAKA}

Alawiyah, (2016). jurnal pendidikan dan ekonomi. jurnal pendidikan dan ekonomi , 5.

Al Arif, M. Nur Rianto. 2016.Dasar-Dasar Pemasaran Bank Syariah. Bandung:Alfabeta.

Arikunto, Suharsimi., (2016). Prosedur Penelitian Suatu Pendekatan Praktik. Jakarta: Rineka Cipta

Bank Indonesia. (2007). Surat Edaran No.9/12/DPNP Tentang Pelaksanaan Good Corporate Governance Bagi Bank Umum. Jakarta: Bank Indonesia.

Bank Indonesia (2011). Peraturan Bank Indonesia No.13/1/PBI/2011 Tentang Penilaian Tingkat Kesehatan Bank Umum. Jakarta : Bank Indonesia .

Bank Indonesia (2004) Peraturan Bank Indonesia No.10/1/PBI/2004 Tentang Ketentuan Umum Sistem Penilaian Tingkat Kesehatan Bank Umum,Jakarta : Bank Indonesia

Hery. (2018). Analisis Laporan Keuangan I,ntegrated and Comporehesive Edition. Jakarta: PT. Grasindo. kasmir. (2016). analisis laporan keuangan. jakarta: PT Raja Grafindo Persada.

Nazir, Muhammad. (2014). Metode Penelitian. Bogor: Ghalia Indonesia

Peraturan Otoritas Jasa Keuangan No.33/POJK.04/2014 Tentang Direksi dan Dewan Komisaris Emiten atau Perusahaan Publik

Sugiyono. (2017 ). Metode Penelitian Bisnis Pendekatan Kuantitatif, Kualitatif, dan RED. Bandung: Alfabeta, CV.

www.ojk.co.id 